\title{
Deficit Irrigation Management in Arid Regions by Adding Biochar to Sandy Soils: Sweet Pepper Cultivation
}

\author{
El-Shawadfy M. A. and Abdelraouf R. E.
}

Water Relations and Field Irrigation Department, Agricultural and Biological Division, National Research Centre, 33 EL Buhouth St., Dokki, Giza, Egypt, Postal Code: 12622.

\author{
Received: 15 August 2019/ Accepted 10 Oct. 2019 / Publication date: 20 Oct. 2019
}

\begin{abstract}
Promoting the rationalization of water consumption and the growth of plants under deficit of irrigation water are major concerns in arid and semi-arid areas. It is necessary to use safe and environmentally friendly methods and treatments for this purpose to overcome water shortage problems with special emphasis on sustainable resource management and environmental protection. Two field experiments were carried out during growing seasons 2017 and 2018 to study the effect of adding biochar on application efficiency of irrigation water, yield of sweet pepper (YSP), water productivity (WP) and vitamin $\mathrm{C}$ of sweet pepper under irrigation scheduling based on deficit irrigation conditions. Three application rates of biochar [0 (control) ,3.5, 7 and 10.5 ton ha.-1] were used under three levels from irrigation water treatments $[100 \%$ Full Irrigation, (FI), $\{75 \%$ of FI and $50 \%$ of FI (deficit irrigation) $\}$ from irrigation requirements for sweet pepper ]. The results revealed that increasing the application of biochar materials under deficit irrigation conditions had a positive impact o YSP, WP and vitamin C of sweet pepper. The most effective level in this regard when plant were irrigated with FI and adding 10.5 ton $\mathrm{ha}^{-1}$ of bioshar as well as when plant were irrigated with 75 $\%$ FI and adding 10.5 ton ha ${ }^{-1}$ of bioshar in both seasons of 2017 and 2018 respectively. A similar direction was observed with vitamin $\mathrm{C}$ content of sweet pepper compared with control treatments and irrigation with $50 \%$ of FI without adding biochar. In addition, water productivity parameter were significantly improved by application of adding biochar under irrigation treatments. The potential function of biochar on soil and yield under deficit of irrigation water for sweet pepper plants was discussed.
\end{abstract}

Keywords: Deficit irrigation, Biochar, Sandy soils, Yield, Water productivity, Sweet pepper

\section{Introduction}

In Egypt, water scarcity is one of the main challenges facing crop production, which requires reducing water consumption in irrigation by improving technologies and new methods that can help to use these precious inputs in a positive and efficient manner (Abdelraouf et al, 2013).Reducing the gap between population consumption and crop production can be achieved through the development of agricultural practices, particularly in arid region such as irrigation methods (Bakry et al., 2013). Due to the limited water resources in Egypt, so that crop water productivity (WP) takes great and important attention (Hozayn et al., 2013). On all over the world, the water scarcity is the main reason of reduction crop yields. Therefore, the use of irrigation water should be appropriate and the principles of deficit irrigation should be accepted with a simple level of reduction in yield (ELMetwally, 2015).In arid regions, deficit irrigation has been widely assessed as a useful and sustainable production method. This practice aims to maximize water productivity of crops. Research results confirm that deficit irrigation is positive and successful in improving and increasing the water productivity of many crops without severe decreasing on yield (Geerts and Raes, 2009). Deficit irrigation is very useful and important for increasing the water use efficiency in the view limitation of water resources in agricultural. It is necessary to know the most sensitive stage of crops and the impact of deficit irrigation on crop yield (Bhagyawant et al., 2015). The dry land area covers about $47.2 \%$ of the earth land area. In dry lands, there are restrictions on arable land, but we have to

Corresponding Author: Abdelraouf R. E., Water Relations and Field Irrigation Department, Agricultural and Biological Division, National Research Centre ,33 EL Buhouth St., Dokki, Giza, Egypt, Postal Code: 12622. E-mailabdelrouf2000@yahoo.com 
cultivate on these poor soils area. (Reynolds and Stafford, 2002).The poorsoilareas are described as sandy soils (Lal, 2003). Sandy soils are believe marginal for the agricultural production (Ayarza et al, 2005). In most sandy soils, reduced carbon content and nutrient availability in organic soils are among the major agricultural constraints. In addition, due to the above constraints, there are other indicators of soil such as low water retention capacity, centered mineralization of soils organic matter and also, soil nutrient leaching.......etc. For these constraints, cultivation in sandy soils on dry areas relies strongly on the use of external inputs like inorganic and organic fertilizers (Guiller et al., 1997).The application rates of composts and organic manures to the soil were successfully and useful used to increase availability nutrient (Goyal et al, 1999). Indicated the importance of rice straw as a sustainable material and using it as a mulching in mitigation of irrigation water deficit under arid regions conditions (Abdelraouf et al., 2013).Contrariwise, organic amendments in sandy soils face a high rate of decomposition and usually the organic matter added in minerals through only small growing seasons (Glaser et al., 2001).Consequently, amendments of organic should be added frequently to maintain productivity in sandy soils. Added compost is importance to reduce water stress under sandy soil and arid areas conditions (Abdelraouf et al., 2013). Sustainable technique uses more stable organic materials that can preserve the sandy soil environment, and also, biochar can be a very good and useful choice to replace organic manures biodegradable easily (Glaser et al., 2002), (Lehmann, et al., 2003).

Biochar is a black carbon derived from biomass and is produced from carbonaceous materials by pyrolysis at $300-500{ }^{\circ} \mathrm{C}$ under limitation of oxygen (Antal and Gronli 2003). Biochar application on the soil is also used to overcome some of the constraints encountered during the cultivation of sandy soils, allowing the provision and given an additional option of soil management in addition to other sustainable and organic materials such as compost, mineral fertilizer and manures. There are many environmental and sustainability benefits of biochar compare with organic manures or compost. It is a porous material with a high internal surface area that can help to retain and conserve more water and also increase the saturated hydraulic conductivity of surface soils (Asai et al., 2009). Biochar was added at many and different rates to sandy soils. Use rates have been significantly effected on soil properties, and the highest application of doses had more effects. Thus, interest in the application of biochar as a technique to mitigate and reduce the effects of global warming is steadily increasing (Beesley et al., 2011; Cabrera et al., 2011). Biochar physicochemical properties can cause and make changes in the availability of $\mathrm{C}$ and soil nutrients, as well as provide and give physical protection to the soil microorganisms against predators and droughts; this may alter soil microbial diversity (Lehmann et al., 2011). Biochar is derived under low-temperature pyrolysis and has a high content of volatile matter that has easy and simple biodegradable substrates, which can help and support the growth of plant growth (Robertson et al., 2012; Mukherjee and Zimmerman, 2013). Biochar structure is derived from high-temperature pyrolysis and has a large surface area as well as aromatic carbon content, which may increase the adsorption capacity and the rebellious character (for carbon sequestration) (Lehmann, 2007).The aim of this study was deficit irrigation management in arid regions under using biochar as a soil amendments.

\section{Materials and Methods}

\section{Experimental location:}

Two field experiments were carried out during two seasons of 2017 and 2018 on sweet pepper at the Experimental Farm of National Research Center, was located in north Cairo-Egypt on sandy soil at Al-Nubariya Region, (latitude 30o $26^{\prime} 28^{\prime}$ 'N, longitude 30o 18' 0' ' E, and mean altitude above sea level $21 \mathrm{~m}$ ), Al Buhayra governorate, Egypt. The selected area characterized with an arid climate, cool winters and hot dry summers.

\section{Physical and chemical properties of soil and irrigation water:}

Soil mechanical and chemical properties and analysis of irrigation water of the experimental site are presented in Tables (1 and 2). 

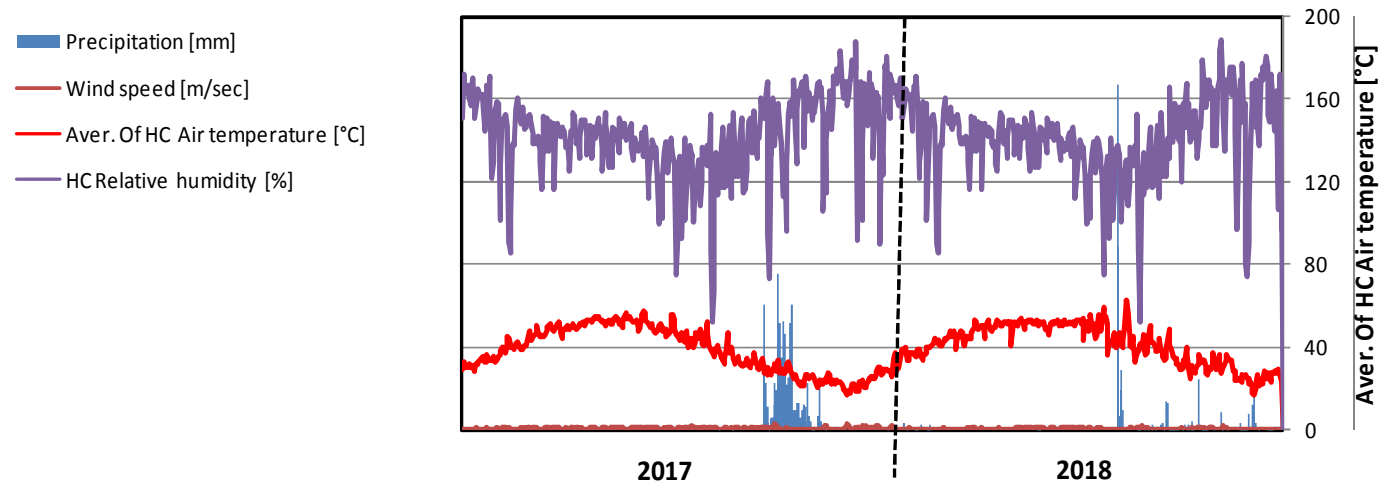

Fig. 1: The data of average temperature, relative humidity and wind speed were obtained from the meteorological data of the Central Laboratory for Agricultural Climate (CLAC), weather station for El-Nubaryia region.

Table 1: Physical and chemical characteristics of the soil of the experimental area

\begin{tabular}{lccc}
\hline \multirow{2}{*}{ Soil Characteristics } & \multicolumn{3}{c}{ Soil depth (cm) } \\
\cline { 2 - 4 } & $\mathbf{0 - 2 0}$ & $\mathbf{2 0 - 4 0}$ & $\mathbf{4 0 - 6 0}$ \\
\hline Physical parameters & & & Sandy \\
\hline Texture & Sandy & Sandy & 40.72 \\
Course sand (\%) & 47.00 & 57.22 & 55.44 \\
Fine sand (\%) & 50.49 & 39.52 & 3.84 \\
Silt + clay (\%) & 2.51 & 3.26 & 1.69 \\
\hline Bulk density (t m-3) & 1.68 & 1.66 & 0.25 \\
Organic matter (\%) & 0.65 & 0.40 & 0.55 \\
\hline Chemical parameters & & & 8.7 \\
\hline EC (dS m-1) & 0.58 & 0.57 & 4.62 \\
pH (1:2.5) & 8.5 & 8.6 & \\
Total CaCO3 (\%) & 7.06 & 2.43 & \\
\hline
\end{tabular}

Table 2: Main characteristics of irrigation water of the experimental area

\begin{tabular}{lc}
\hline Parameter & Irrigation canal water, IW \\
\hline Electric Conductivity, dS m-1 & 0.54 \\
$\mathrm{pH}$ & 7.4 \\
\hline Chemical characteristics, concentrations in mg l-1 & \\
\hline Calcium, Ca2+ & 2.63 \\
Magnesium, Mg2+ & 1.42 \\
Sodium, Na2+ & 1.59 \\
Potassium, K+ & 0.13 \\
Carbonate, CO32- & $<0.01$ \\
Bicarbonate, HCO3- & 1.60 \\
Chloride, Cl- & 2.70 \\
Sulphate, SO42- & 1.30 \\
\hline
\end{tabular}

\section{Biochar production method:}

Pyrolysis experiments were carried out by simple reactors for producing biochar from corn straw using metal scrap drums (MSD). The feedstock (corn straw) was placed in the reactor to pyrolysis at low - temperatures. After pyrolysis, the reactor was left inside the furnace to cool to room temperature. The biochar and ash obtained were weighted as shown in figure (2). 


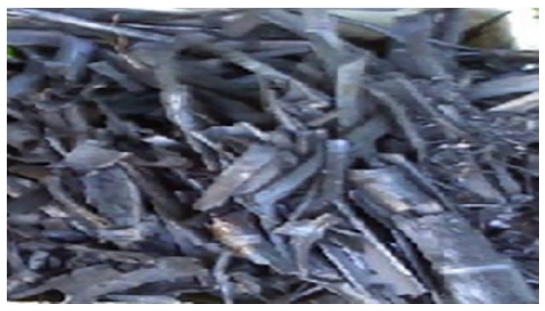

Corn straw biochar

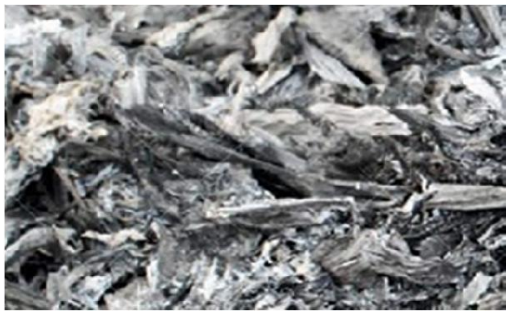

Corn straw Ash

Fig. 2: Biochar and ash produced from corn straw

\section{Irrigation requirements for sweet pepper:}

Daily irrigation water was calculated by following equation (1) and seasonal irrigation water was $5760 \mathrm{~m} 3 / \mathrm{ha}$./season for 100\% full irrigation "FI" for 2017 and $6000 \mathrm{~m} 3 / \mathrm{ha}$./season for 2018 under drip irrigation system:

$$
\mathrm{IRg}=[(\mathrm{ETO} \times \mathrm{Kc} \times \mathrm{Kr}) / \mathrm{Ei}]-\mathrm{R}+\mathrm{LR}
$$

Where: $\mathrm{IRg}=$ Gross irrigation requirements, $\mathrm{mm} /$ day; ETO= Reference evapotranspiration, $\mathrm{mm} / \mathrm{day}$, $\mathrm{Kc}=$ Crop factor $(\mathrm{FAO}-56) ; \mathrm{Kr}=$ Ground cover reduction factor and the values of $\mathrm{Kr}$ measured by Keller equation: $\mathrm{Kr}=\mathrm{GC} \%+0$, 15. $(1-\mathrm{GC} \%)$, Where $\mathrm{GC} \%$ : ground cover = (shaded area per plant/area per plant); Ei = Irrigation efficiency, $\%, \mathrm{R}=$ Water received by plant from sources other than irrigation, $\mathrm{mm}$ (for example rainfall), LR = Amount of water required for the leaching of salts, $\mathrm{mm}$. Total water volumes for each treatment and application rate of biochar were reported in table (3)

Table 3: Total water volumes and biochar rates during 2017 and 2018 seasons for each treatment

\begin{tabular}{cccccc}
\hline $\begin{array}{c}\text { Deficit Irrigation, } \\
\left(\mathbf{m}^{\mathbf{3}}\right)\end{array}$ & Symbol & \multicolumn{2}{c}{$\begin{array}{c}\text { Irrigation volumes } \\
\left(\mathbf{m}^{\mathbf{3}} \mathbf{h a}^{-\mathbf{1}}\right)\end{array}$} & $\begin{array}{c}\text { Biochar rates, } \\
\left(\text { ton ha. }{ }^{-1}\right)\end{array}$ & Symbol \\
\hline $\mathbf{1 0 0 \%}$ of FI & F1 & 5760 & 6000 & 0 & BR0 \\
$\mathbf{7 5 \%}$ of FI & F2 & 4320 & 4500 & 3.5 & BR1 \\
$\mathbf{5 0 \%}$ of FI & F3 & 2880 & 3000 & 7.0 & BR2 \\
& & & & 10.5 & BR3 \\
\hline
\end{tabular}

FI: Full Irrigation

\section{Evaluation Parameters}

Application efficiency of irrigation water "AEIW: Application efficiency relates to the actual storage of water in the root zone to meet the crop water needs in relation to the water applied to the field. According to El-Meseery, (2003) application efficiency "AEIW" was calculated using the following relation (2):

$$
\mathrm{AEIW}=\mathrm{Ds} / \mathrm{Da}
$$

Where: AEIW = Application efficiency of irrigation water, $(\%)$, Ds $=$ Depth of stored water in root zone $(\mathrm{cm})$ calculated by equation, where: $\mathrm{Ds}=(\theta 1-\theta 2) * \mathrm{~d} * \rho$ where, Da $=$ Depth of applied water $(\mathrm{cm}), \mathrm{d}=$ Soil layer depth $(\mathrm{cm}), \theta 1=$ Soil moisture content after irrigation $(\%), \theta 2=$ Soil moisture content before irrigation $(\%), \rho=$ Relative bulk density of soil (dimensionless).

Yield of sweet pepper: At harvest, yield as $\mathrm{kg}$ per $\mathrm{m} 2$ and ton per hectare were calculated.

Water productivity of sweet pepper "WP sweet pepper" was calculated according to James, (1988) by equation (3) as follows:

$$
\text { WPsweet pepper }=\mathrm{Ey} / \mathrm{Ir}
$$

Where: WPsweet pepper is water productivity of sweet pepper (kg sweet pepper / m3water), Ey: is the economical yield ( $\mathrm{kg} / \mathrm{ha}$.); Ir: is the applied amount of irrigation water (m3water /ha./season). 
Vitamin C of sweet pepper: At harvesting time, samples of green pepper fruits were randomly harvested from each sub-plot to measure vitamin C.

\section{Experimental design:}

The experimental design was split plot with three levels of irrigation water treatments $[100 \%$ Full Irrigation, (FI), $\{75 \%$ of FI and $50 \%$ of FI (deficit irrigation) $\}$ from irrigation requirements for sweet pepper ] and three application rates of biochar [0 (control) , 3.5, 7 and 10.5 ton/ha.] were put in main plots and sub-main plots, respectively with three replications as shown in figure (3).

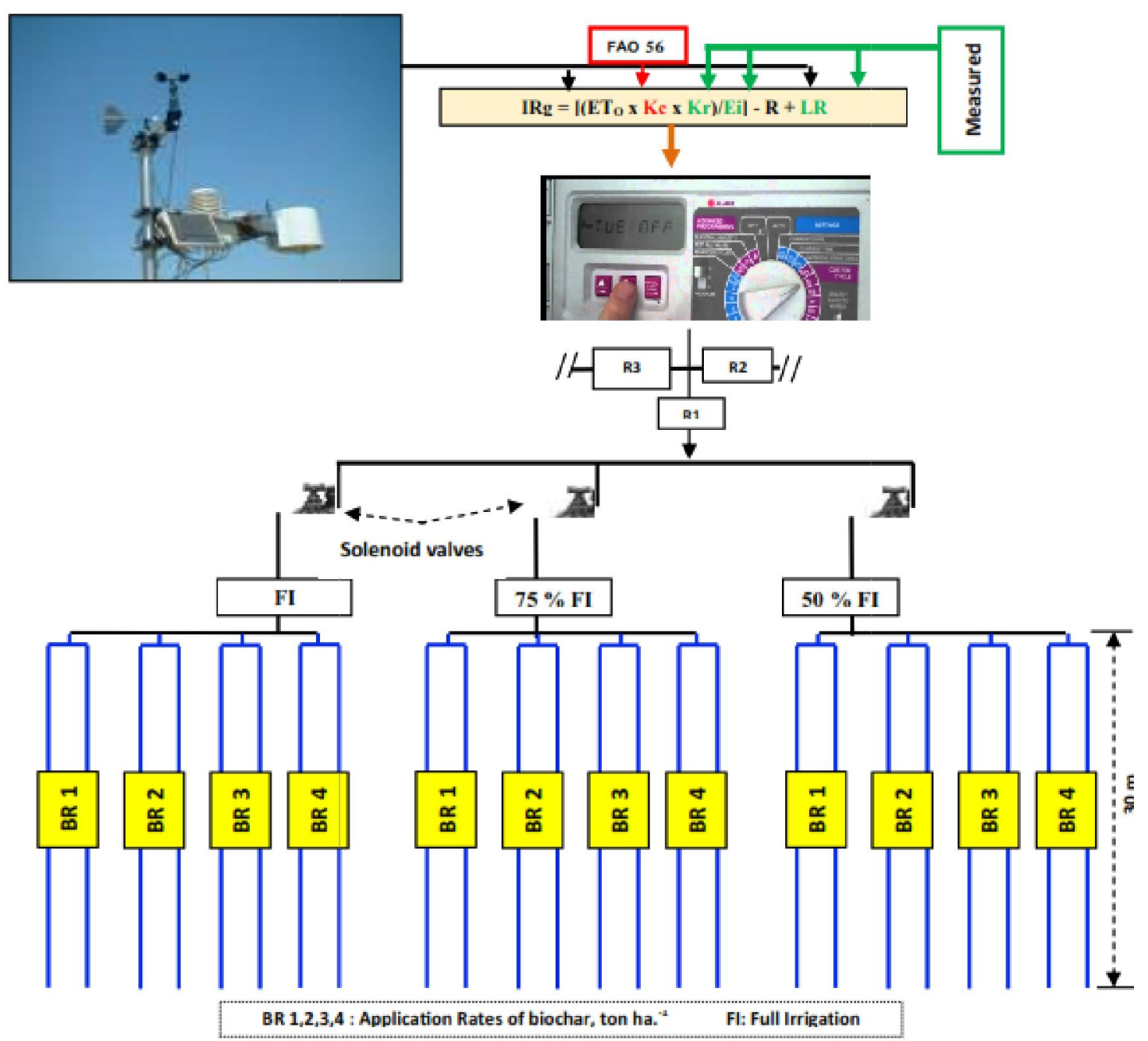

Fig. 3: Layout of experimental design

\section{Statistical Analysis:}

Data were subjected to the proper statistical analysis according to the method prescribed by Snedecor and Cochran (1980). However, means were verified according to the Least Significant Difference (LSD).

\section{Results and Discussion}

\section{Application efficiency of irrigation water}

Irrigation application efficiency (AEIW) as affected by deficit irrigation and biochar application rate is shown in Fig. (4). It could be seen that the application efficiency increased with 
decreasing the applied amount of irrigation water and increasing the application rate of biochar in both seasons. The highest value of AEIW was achieved under $50 \%$ of FI and with adding 10.5 ton ha1, where recorded $97.2 \%$ and $94.8 \%$ on seasons 2017 and 2018 respectively. Meanwhile, under FI and without adding biochar the AEIW was recorded $75.7 \%$ and $73.44 \%$ on both seasons, respectively. The increasing of AEIW might be attributed to the interaction of two factors; the stored and reducing the volume of water which loss from root zone (deep percolation) by decreasing amount of applied irrigation water in side root zone and reducing total amount of irrigation water hence, that this may will be make the plants to suffer from drought stress due to the amount of irrigation water which be added is less than the required amount and enhancing the water holding capacity within root zone by increasing the application rate of biochar. These results agreed with Abdelraouf, (2014); Asai,et al., (2009) and Lehmann (2007).

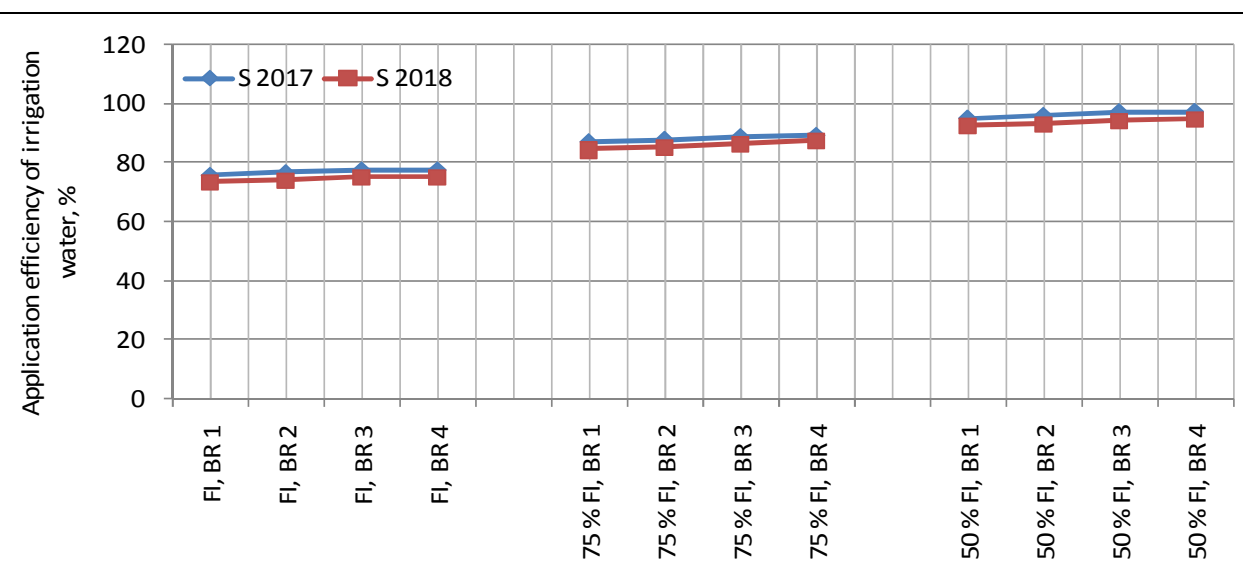

Fig. 4: Effect of deficit irrigation and application rate of biochar on application efficiency of irrigation water during 2017 and 2018 seasons

\section{Effect of deficit irrigation}

\section{1- yield of sweet pepper "YSP"}

Data in Table ( 4 ) showed that significant differences were detected due to variation in applied water amounts in yield of sweet pepper, where the highest values were achieved by $100 \%$ of FI followed by $75 \%$ of FI on both seasons, respectively compared with the lowest value was occurred under $50 \%$ of FI. The convergence of the results between the two treatments $100 \%$ of FI and $75 \%$ of FI may be due to increasing concentration of mineral fertilizers in root zone when adding $75 \%$ of FI.

\section{2- Water productivity of sweet pepper "WP sweet pepper"}

Effect of deficit irrigation on water productivity of sweet pepper "WP sweet pepper" is illustrated in Table (4). Data are shown that WP sweet pepper was affected by water application rate. Decreasing water amount to $75 \%$ of FI resulted the highest values for WP sweet pepper (5.88 and 5.48 ) followed by $75 \%$ of FI resulted values for WP sweet pepper ( 5.35 and 4.98 ) in both seasons 2017 and 2018 respectively. While the lowest values of WP sweet pepper were obtained FI irrigation water amount. The increase of WP sweet pepper may be due to the small amount of irrigation water stored inside the root zone.

\section{3- Vitamin C of sweet pepper "V.C"}

Data illustrated in Tables (4) contain the effect of deficit irrigation, i.e. FI , 75\% of FI and $50 \%$ of FI of crop evapotraspiration (ETo) on V.C. of sweet pepper in 2017 and 2018 respectively. It is clear from Tables (4) that a quite similar trend was obtained in both experimental seasons regarding the effect of deficit irrigation on V.C. of sweet pepper. In both seasons the highest values were recorded 112.3 and 110, under FI in both seasons respectively. However, V.C. of sweet pepper showed its lowest values when plants were irrigated at $50 \%$ of FI in both seasons respectively. 


\section{Effect of application rate of biochr}

\section{1- yield of sweet pepper "YSP"}

Effect of biochar application rate on YSP is presented in Table (4). During seasons 2017 and 2018, the highest values of YSP were recorded (24.35 ton ha-1 and 23.62 ton ha-1 ) when the soil was treated with adding 10.5 ton ha-1; while the lowest values of YSP were recorded 19.19 ton ha- 1 and 18.62 ton ha-1 when the soil non treated with biochar during seasons 2017 and 2018 respectively. Increasing of YSP might be due to the interaction of two important elements;1) Addition of biochar which caused increasing the water holding capacity inside root zone and then enhancing the AEIW hence, mitigation the water stress on plants; 2) Enrich growth area with available nutrients as a result of the degradation of biochar.

Table 4: Effect of various treatments on yield, water productivity and vitamin $\mathrm{C}$ of sweet pepper during 2017 and 2018 seasons

\begin{tabular}{|c|c|c|c|c|c|c|c|}
\hline \multirow{2}{*}{$\begin{array}{c}\text { Irrigation } \\
\text { Deficit }\end{array}$} & \multirow{2}{*}{$\begin{array}{c}\text { Biochar } \\
\text { rate } \\
\left(\text { ton. } \text { ha }^{-1}\right)\end{array}$} & \multicolumn{2}{|c|}{$\begin{array}{l}\text { Yield of fruits } \\
\left.\text { (ton ha.- }{ }^{-1}\right)\end{array}$} & \multicolumn{2}{|c|}{$\begin{array}{l}\text { Water productivity } \\
\text { (kg sweet pepper } \mathrm{m}^{3} \text { water) }\end{array}$} & \multicolumn{2}{|c|}{ Vitamin C } \\
\hline & & 2017 & 2018 & 2017 & 2018 & 2017 & 2018 \\
\hline \multicolumn{8}{|c|}{ Effect of deficit irrigation on yield, water productivity and vitamin $C$ of sweet pepper } \\
\hline FI & & $25.67 \mathrm{a}$ & $24.91 \mathrm{a}$ & 4.46 & 4.15 & 112.3 & 110.0 \\
\hline $75 \%$ FI & & $25.42 \mathrm{~b}$ & $24.65 \mathrm{~b}$ & 5.88 & 5.48 & 106.7 & 104.6 \\
\hline $50 \%$ FI & & $15.40 \mathrm{c}$ & $14.94 \mathrm{c}$ & 5.35 & 4.98 & 84.22 & 82.54 \\
\hline LSD at $5 \%$ & & 0.1014 & 0.1014 & & & & \\
\hline \multicolumn{8}{|c|}{ Effect of biochar rate on yield, water productivity and vitamin $C$ of sweet pepper } \\
\hline & 0 & $19.19 \mathrm{c}$ & $18.62 \mathrm{c}$ & 4.53 & 4.22 & 90.18 & 88.37 \\
\hline & 3.5 & $22.24 \mathrm{~b}$ & $21.58 \mathrm{~b}$ & 5.25 & 4.89 & 102.7 & 100.7 \\
\hline & 7 & $22.88 \mathrm{~b}$ & $22.19 b$ & 5.40 & 5.03 & 104.1 & 102.0 \\
\hline & 10.5 & $24.35 \mathrm{a}$ & $23.62 \mathrm{a}$ & 5.74 & 5.35 & 107.3 & 105.2 \\
\hline LSD at $5 \%$ & & 0.6577 & 0.6380 & & & & \\
\hline
\end{tabular}

FI: Full irrigation

\section{2- Water productivity of sweet pepper "WP sweet pepper"}

From Table (4) data regarding the effect of application rate of biochar on WP sweet pepper, showed that WP sweet pepper had significant variation respond to the effect of application rate of biochar in both the first and the second season, where the highest values were achieved by using 10.5 ton ha-1 followed by using 7 ton ha-1in both seasons respectively. On the other hand, application rate of biochar by using 3.5 ton ha- 1 showed the lowest values followed by non-adding. Increase in WP sweet pepper may be due to the same reasons of increasing sweet pepper productivity.

\section{3- Vitamin C of sweet pepper "V.C"}

Data regarding the effect of application rate of biochr on V.C. of sweet pepper parameter in the first and second seasons are presented in Table (4), The highest values of V.C. of sweet pepper (107.3 and 105.2) were obtained under the treatment of adding10.5 ton ha-1, while it recorded (90.18 and 88.37) under treatment of no adding of biochar in 2017 and 2018 seasons respectively. Increasing V.C of sweet pepper may be due to the interaction of two factors. 1) The addition of biochar in the soil leads to increased water holding capacity inside the root zone and then to the improvement of AEIW and thus, relieving water pressure within the root zone; 2) Supply the growth area with available nutrients as a result of the degradation of biochar.

\section{Effect of interaction}

\section{1- yield of sweet pepper "YSP"}

Effect of interaction between deficit irrigation and application rate of biochar on YSP is exhibited in Fig. (5) and Table (5).Significant differences due to interaction were attained in YSP in both experimental seasons. It is worthy to mention that in most cases the highest values of the significantly affected character in the two seasons were exhibited by added 10.5 ton ha ${ }^{-1}$ of biochar when the plants were irrigated at either FI or $75 \%$ of FI. Meanwhile, the lowest significant interaction 
values of YSP were 13.34ton. $\mathrm{ha}^{-1}$ and 12.94 ton. $\mathrm{ha}^{-1}$ in the first and second season, respectively 1 with $50 \%$ of FI and without adding biochar. The main reasons for the improvement of YSP under $75 \%$ of FI and the addition 10.5 tons. ha $^{-1}$ of biochar may be due to; 1)The addition of $75 \%$ of FI reduces the total volume of water which stored in the root zone and thus reduces the loss by deep percolation thereby increasing the concentration of mineral fertilizer within the root zone and allowing the opportunity to increase nutrient absorption, 2) Increased rate of biochar that improved water holding capacity inside root zone resulting in enhanced AEIW and 3) The decomposition of biochar resulted to increase the availability nutrients.

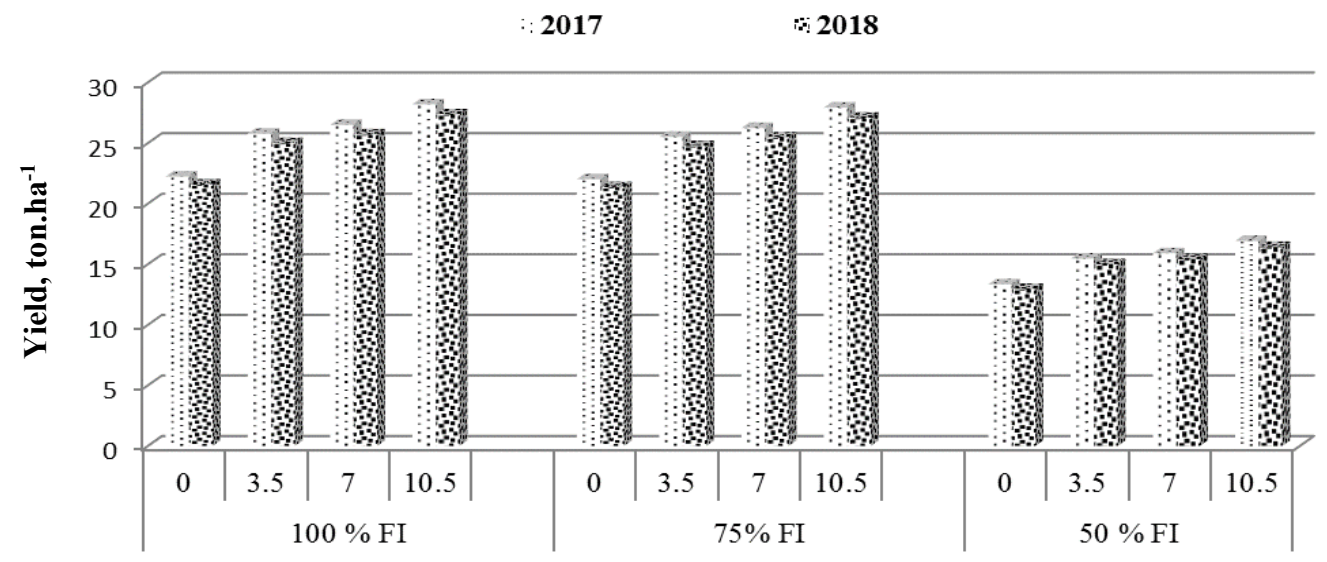

Treatments

Fig. 5: Effect of the interaction between deficit irrigation and application rate of biochar on water productivity of sweet pepper during 2017 and 2018 seasons

\section{2- Water productivity of sweet pepper "WP sweet pepper"}

Data regarding the effect of the interaction between Effect of deficit irrigation and Effect of application rate of biochr water productivity of sweet pepper "WP sweet pepper" parameter in the first and second seasons are presented in Table (5) and Fig. (6).

Table 5: Effect of interaction between deficit irrigation and application rate of biochar on yield, water productivity and vitamin C of sweet pepper during 2017 and 2018 seasons

\begin{tabular}{cccccccc}
\hline $\begin{array}{c}\text { Irrigation } \\
\text { Deficit }\end{array}$ & $\begin{array}{c}\text { Biochar } \\
\text { rate } \\
\text { (ton. ha }^{-1} \text { ) }\end{array}$ & \multicolumn{2}{c}{$\begin{array}{c}\text { Yield of fruits } \\
\text { (tonha.-1) }\end{array}$} & $\begin{array}{c}\text { Water productivity } \\
\text { (kg sweet pepper } \mathbf{~ m - ~}\end{array}$ & \multicolumn{2}{c}{ Vitamin C } \\
3water) & $\mathbf{2 0 1 7}$ & $\mathbf{2 0 1 8}$ & $\mathbf{2 0 1 7}$ & $\mathbf{2 0 1 8}$ & $\mathbf{2 0 1 7}$ & $\mathbf{2 0 1 8}$ \\
\hline & 0 & $22.23 \mathrm{c}$ & $21.57 \mathrm{c}$ & 3.86 & 3.59 & 100.2 & 98.18 \\
FI & 3.5 & $25.77 \mathrm{~b}$ & $24.99 \mathrm{~b}$ & 4.47 & 4.17 & 114.1 & 111.8 \\
& 7 & $26.50 \mathrm{~b}$ & $25.71 \mathrm{~b}$ & 4.60 & 4.28 & 115.7 & 113.4 \\
& 10.5 & $28.20 \mathrm{a}$ & $27.36 \mathrm{a}$ & 4.89 & 4.56 & 119.2 & 116.8 \\
& 0 & $22.01 \mathrm{c}$ & $21.35 \mathrm{c}$ & 5.09 & 4.74 & 95.21 & 93.31 \\
$\mathbf{7 5 \%}$ FI & 3.5 & $25.51 \mathrm{~b}$ & $24.74 \mathrm{~b}$ & 5.91 & 5.50 & 108.4 & 106.3 \\
& 7 & $26.24 \mathrm{~b}$ & $25.45 \mathrm{~b}$ & 6.07 & 5.65 & 109.9 & 107.7 \\
& 10.5 & $27.92 \mathrm{a}$ & $27.08 \mathrm{a}$ & 6.46 & 6.02 & 113.3 & 111.0 \\
$\mathbf{5 0 \%}$ FI & 0 & $13.34 \mathrm{f}$ & $12.94 \mathrm{f}$ & 4.63 & 4.31 & 75.14 & 73.63 \\
& 3.5 & $15.46 \mathrm{e}$ & $15.00 \mathrm{e}$ & 5.37 & 5.00 & 85.58 & 83.87 \\
& 7 & $15.90 \mathrm{de}$ & $15.42 \mathrm{de}$ & 5.52 & 5.14 & 86.75 & 85.01 \\
LSD at 5\% & 10.5 & $16.92 \mathrm{~d}$ & $16.41 \mathrm{~d}$ & 5.88 & 5.47 & 89.42 & 87.63 \\
\hline
\end{tabular}

FI: Full irrigation 


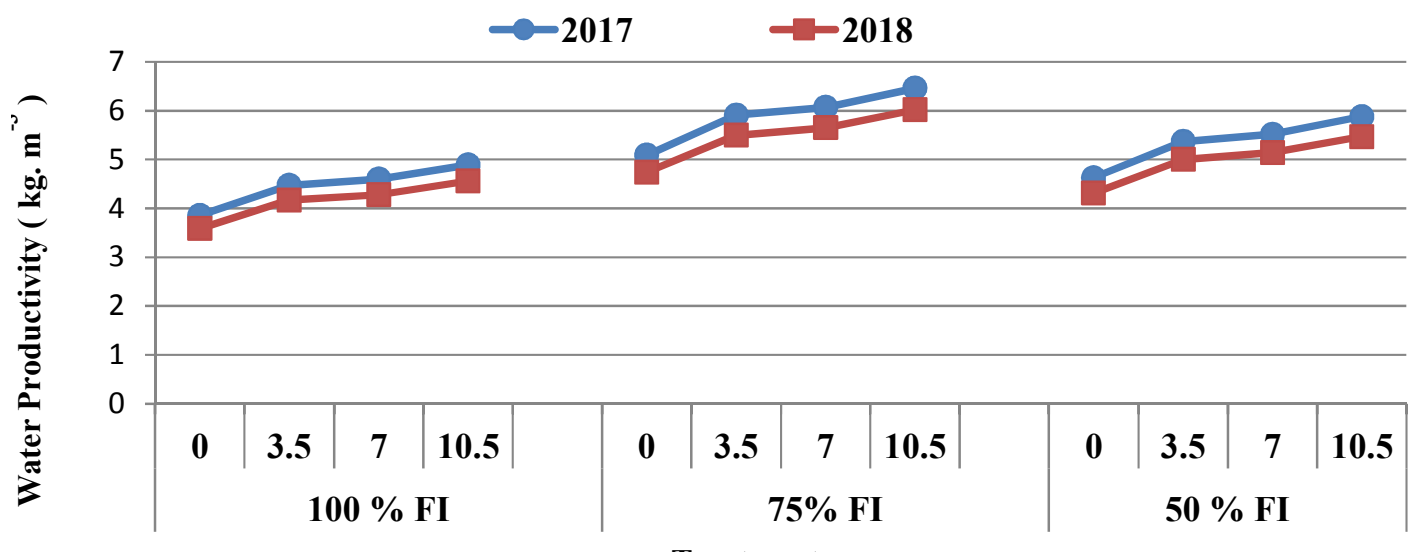

Treatments

Figure 6: Effect of the interaction between deficit irrigation and application rate of biochar on water productivity of sweet pepper during 2017 and 2018 seasons

It is worthy to mention that studied WP sweet pepper was significantly affected by the interaction in both experimental seasons. The highest values of WP sweet pepper were obtained by using $75 \%$ of FI under the rate of adding 10.5 ton ha $^{-1}$ of biochr followed by using $75 \%$ of FI under the rate of adding 7 ton $\mathrm{ha}^{-1}$ of biochr in the first season 2017 and second season 2018 respectively. Meanwhile, the lowest significant interaction values of WP sweet pepper were 3.86 and $3.59 \mathrm{~kg}$ sweet pepper m-3 water in the first and second season, respectively when plants were irrigated at FI under non adding of biochar.

\section{3- Vitamin C of sweet pepper "V.C"}

Effect of interaction between deficit irrigation and application rate of biochar on vitamin $\mathrm{C}$ of sweet pepper is exhibited in Table (5) and Fig (7). Significant differences due to interaction were attained in vitamin $\mathrm{C}$ parameter in both experimental seasons.

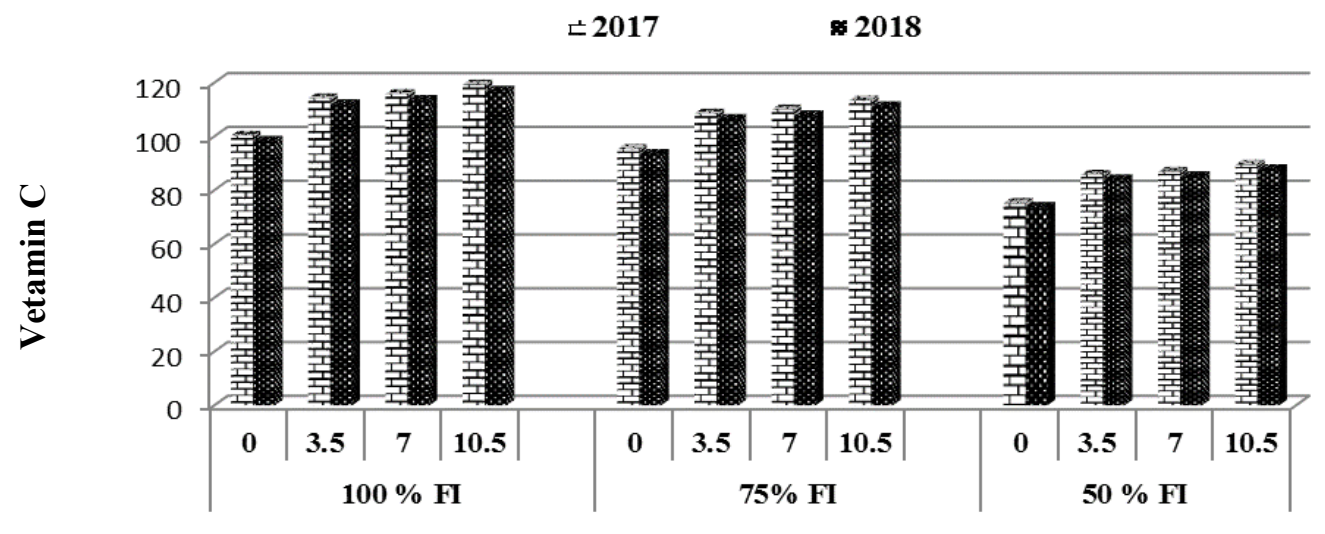

Treatments

Fig. 7: Effect of the interaction between deficit irrigation and application rate of biochar on vitamin $C$ of sweet pepper during 2017 and 2018 seasons

The highest significant interaction values of vitamin C (119.2 and 116.8) in the first and second season, respectively were obtained from irrigation at FI under the rate of adding 10.5 ton ha $^{-1}$ of biochr. Meanwhile, the lowest significant interaction values of vitamin C (75.14 in the first season and 73.63 in the second season), were obtained from irrigation at $50 \%$ of FI under non adding of 
biochr. The main causes for increase vitamin $\mathrm{C}$ of sweet pepper under FI and using 10.5 tons.ha $^{-1}$ of biochar, this may be due to: 1) Increasing of application rate of biochar, which increase the water holding capacity inside root zone leading to enhanced and mitigate water stress on plants; 2) Degradation of biochar increased the availability of nutrients.

\section{Conclusion}

From the results of this study, it can be concluded that increasing the application of biochar materials under deficit irrigation conditions had a positive impact on YSP, WP and vitamin C of sweet pepper in sandy soil. Application using biochar [0 (control) ,3.5, 7 and 10.5 ton ha.-1] in combination with irrigation water treatments $[100 \%$ Full Irrigation, (FI) , $\{75 \%$ of FI and $50 \%$ of FI (deficit irrigation)\} from irrigation requirements for sweet pepper ], can minimize the problems of water stress. Under the conditions of Sandy soil in Egypt, irrigation with FI and adding 10.5 ton $\mathrm{ha}^{-1}$ of bioshar as well as irrigation with $75 \%$ of FI and adding 10.5 ton ha ${ }^{-1}$ of bioshar is recommended.

\section{References}

A.O.A.C., 1990. Association of Official Agricultural Chemists. Official Methods of Analysis. 4th ed. pp. 495-510. Benjamin Franklin Station, Washington. D.C., U.S.A.

Abdelraouf, R. E.; A. B. Bakry, and M. H. Taha, 2013. Effect of pulse drip irrigation and mulching systems on yield, quality traits and irrigation water use efficiency of soybean under sandy soil conditions. Agricultural Sciences, 4 (5): 249-261.

Abdelraouf, R.E., 2014. New Engineering Method to Improve Water Use Efficiency of Maize under Drip Irrigation System Using Irregular Volumetric Distribution of Compost along Laterals. Middle East Journal of Agriculture Research, 3(3): 383- 394.

Abdelraouf, R.E., K.M. Refaie, and I.A. Hegab, 2013. Effect of drip lines spacing and adding compost on the yield and irrigation water use efficiency of wheat grown under sandy soil conditions. Journal of Applied Sciences Research, 9(2): 1116-1125.

Abdelraouf, R.E., S.F. El Habbasha, M.H. Taha and K.M. Refaie, 2013. Effect of Irrigation Water Requirements and Fertigation Levels on Growth, Yield and Water Use Efficiency in Wheat Middle-East Journal of Scientific Research, 16 (4): 441-450.

Antal, M. J. and M Gronli, 2003. The art, science, and technology of charcoal production. Ind. Eng. Chem. Res. 42:1619-1640.

Asai, H., B. K. Samson,; H. M.Stephan, K. Songyikhangsuthor, K.Homma, Y. Kiyono, Y.Inoue, T. Shiraiwa, and T. Horie, 2009. Biochar amendment techniques for upland rice production in Northern.

Ayarza, M. L., F.Raucher, L.Vilela,; E.Amezquita, E.Barrios, M.Rondon, and I. Rao, 2005. Sustainable intensification of crop-livestock systems on sandy soils of Latin America: Tradeoffs between production and conservation. Management of Tropical Sandy Soils for Sustainable Agriculture "A Holistic Approach for Sustainable Development of Problem Soils in the Tropics" $27^{\text {th }}$ November - 2nd December 2005 KhonKaen, Thailand, pp. 406-413.

Bakry A. B., O. M. Ibrahim, R. E. Abdelraouf, and E.A. Badr, 2014. Effect of Humic Acid, Mycorrhiza Inoculation, and Biochar on Yield and Water Use Efficiency of Flax under Newly Reclaimed Sandy Soil. Agricultural Sciences, 5, 1427- 1432.

Bakry, A.B, R.E. Abdelraouf and M. Ahmed, 2013. Effect of drought stress and ascorbic acid foliar application on productivity and irrigation water use efficiency of wheat under newly reclaimed sandy soil. Elixir Agriculture 57A 14398-14403

Beesley, L. E. Moreno-Jiménez, J. L.Gomez-Eyles, E. Hrris,; B.Robinson, and T. Sizmur, 2011. A review of biochars' potential role in the remediation, revegetation and restoration of contaminated soils, Environ. Pollut., 159, 3269-3282.

Bhagyawant, R.G., S.D. Gorantiwar, and S.D. Dahiwalkar, 2015. Effect of deficit irrigation on crop growth, yield and quality of onion under surface irrigation. American-Eurasian J. Agric. \& Environ. Sci., 15 (8): 1672-1678. 
Cabrera, A., L.Cox, K. A. Spokas, R. Celis, M. C.Hermosín, J.Cornejo and W. C. Koskinen, 2011. Comparative sorption and leaching study of the herbicides fluometuron and 4-chloro-2 methylphenoxyacetic acid (MCPA) in a soil amended with biochars and other sorbents, J. Agri. Food Chem., 14, 12550-12560.

El-Meseery, A.A., 2003. Effect of different drip irrigation systems on maize yield in sandy soil.The 11th Annual Conference of Misr Society of Agr. Eng., 15-16 Oct., 2003: 576 - 594

El-Metwally, I. M., R. E.Abdelraouf, M. A.Ahmed, O. Mounzer, J. A. Juan and M. T. Abdelhamid, 2015. Response of wheat (Triticum aestivum L.) crop and broad-leaved weeds to different water requirements and weed management in sandy soils. Agriculture (Pol'nohospodárstvo), 61 (1): $22-32$.

Geerts S. and D. Raes, 2009.Deficit irrigation as an on-farm strategy to maximize crop water productivity in dry areas. Agricultural Water Management, 96: 1275-1284.

Glaser, B., R. Bol, N.Preedy, K. B. McTiernan, M. Clark, and W. Amelung, 2001.Short term sequestration of slurry-derived carbon and nitrogen in temperate grassland soil using $13 \mathrm{C}$ and $15 \mathrm{~N}$ natural abundance. J. Plant Nutr., Soil Sci. 164:467-474.

Glaser, B., J. Lehmann, and W. Zech, 2002. Ameliorating physical and chemical properties of highly weathered soils in the tropics with charcoal - a review. Biol. Fertil. Soils, 35:219-230.

Goyal, S., K.Chander, M. C. Mundra and K. K. Kapoor, 1999. Influence of inorganic fertilizers and organic amendments on soil organic matter and soil microbial properties under tropical conditions. Biol. Fertil. Soils, 29:196-200.

Guiller, K. E., J.Cádiz, C.Ehaloitis, W. D. Sácala, and P. L. Mafongoya, 1997. Building soil nitrogen capital in Africa. In Buresh, R. J. and Sanchez, P. A. (eds.). Replenishing Soil fertility in Africa. SSSA Special Publication, 51:151-192.

Hozayn, M., A.A. Abd El Monem, R.E. Abdelraouf and M.M. Abdalla, 2013. Do Magnetic Water Affect Water Use Efficiency, Quality and Yield of Sugar Beet (Beta vulgaris L.) Plant under Arid Regions Conditions? Journal of Agronomy, Volume 12 (1): 1-10.

James L.G., 1988. Principles of farm irrigation system design. John Willey \& sons. Inc., Washington State University. 73:152-153,350-351.

Kirda, C., S.Topcu, H.Kaman, A.C. Ulger, A.Yazici, M. Cetin and M.R. Derici, 2005. Grain yield response and $\mathrm{N}$-fertiliser recovery of maize under deficit irrigation. Field Crops Research, 93: $132-141$.

Lal, R., 2003. Carbon sequestration in dryland ecosystems. Environmental management 33 (4): 528544.

Lehmann, J., 2007. Bio-energy in the black, Frontiers Ecol. Environ., 5, 381-387.

Lehmann, J., M.C. Rillig, J.Thies, C. A. Masiello, W. C. Hockaday and D.Crowley, 2011. Biochar effects on soil biota - A review, Soil Biol. Biochem., 43, 1812-1836.

Lehmann, J., J. P. Silva, C. Steiner, T. Nehls,; W. Zech, and B. Glaser, 2003. Nutrient availability and leaching in an archaeological Anthrosol and a Ferralsol of the Central Amazon basin: Fertilizer, manure and charcoal amendments. Plant Soil 249:343-357.

Mukherjee, A. and A. Zimmerman, 2013. Organic carbon and nutrient release from a range of laboratory-produced biochars and biocharsoil mixtures, Geoderma, 193, 122-130.

Reynolds, J. F. and D. M. S. Stafford Smith, 2002. Do humans cause deserts? In Reynolds, J. F. and Stafford Smith, D. M. (eds). Global Desertification: Do Humans Cause Deserts? J. F. Dahlem Univ. Press, Berlin, pp. 1-21.

Robertson, S.J., M.P. Rutherford, J.C. López-Gutiérrez and H.B. Massicotte, 2012. Biochar enhances seedling growth and alters rootvsymbioses and properties of sub-boreal forest soils, Can. J. Soil Sci., 92, 329-340.

Snedecor, G.W. and W.G. Cochran, 1980. Statistical Methods. Oxford and J.B.H. publishing com. $7^{\text {th }}$ edition, $593 \mathrm{p}$.

Vogel, A., 1968. A Text Book of Quantitative Inorganic Analysis. Longmans, New York, pp. 1216.

Zhao, S. and X. Wang, 2017. Effect of Temperature on the Structural and Physicochemical Properties of Biochar with Apple Tree Branches as Feedstock Material. Energies 2017, 10, 1293 pp 1-15, www.mdpi.com/journal/energies. 